CARLA D. MARTIN ${ }^{1}-$ KATHRYN E. SAMPECK ${ }^{2}$

THE BITTER AND SWEET OF CHOCOLATE IN EUROPE ${ }^{3}$

Dol: 10.18030/sOCIO.HU.2015EN.37

\title{
ABSTRACT
}

This paper examines the changing role of chocolate in European society, especially in light of the food movement turn to slow, small batch, craft chocolate, as a way to critically analyze relationships of labor and race, gender, and class inequality. The changing culture of chocolate consumption over centuries, from its pre-Columbian origins to the ways European colonists culturally and economically adopted chocolate shows a trajectory of increasing permeation of European foods (more foods contain chocolate) and regionalization of tastes in chocolate recipes, most recently by small batch chocolate makers whose work crafts local identity through branding of a tropical product. Europe is the world's biggest importer and processor of cacao as well as the largest per capita consumer of chocolate. Industrial chocolate is higher in sugar and less complex in taste compared to the variety of local chocolate makers, so chocolate occupies an uneasy place in European diets, especially in light of growing rates of obesity and recent "junk food taxes" that target sugary foods. The historical context and analysis of labor in cacao farming and chocolate production shows a critical reliance on coerced labor. While the legacy of the past has been the decoupling of horrific coerced labor in cacao production from the consciousness of everyday chocolate consumers, the growing vitality of small batch chocolate makers refocuses attention on the country of origin--the conditions of production--as well as local, European tastes-the conditions of consumption.

The authors employ interdisciplinary methodologies of close readings of primary sources that include historical recipes, critical analysis of representation in historic and contemporary images and media, and descriptive economic data of export and consumption levels. This systematic study of taste in chocolate and its social, economic, political, and cultural implications is carried out in an analytical framework of the historical contingency of the social construction of realms of value, and that such construction takes place within global and local political economic forces that tend to propagate inequality as a solution to greater economic efficiency. Examining food access and food justice in the light of ways people produce and consume chocolate can challenge assumptions about social inequalities, race, health, and identity and offer insights into long-term sustainability. The critical analysis of these social factors suggests directions for future education, investment, and action by the fine and craft chocolate industry in Europe that can promote mutual benefits for producers and consumers.

Keywords: chocolate, ethics, quality, flavor, anthropology, craft, taste, labor

\footnotetext{
1 Harvard University

2 Illinois State University

3 Presented at The Social Meaning of Food Workshop, The Institute for Sociology, Centre for Social Sciences, Hungarian Academy of Sciences, June 16-17, 2015, Budapest, Hungary
} 
CARLA D. MARTIN - Kathryn E. SAMPECK

\section{The BitTer ANd SWeet of Chocolate in Europe}

\section{INTRODUCTION}

Food is a "source of tension, dispute, and mutual misunderstanding in contemporary Europe" (Delamont 1995:1) such that social struggles can be expressed in terms of taste, with "prejudices directed toward both individuals and the members of particular ethnic groups...expressed, not as ethnic or racial biases, but rather as opinions based in individual tastes...symbolically associated with certain racial and ethnic identities" (Bonner 1999:120). The cultural history of taste - here taken in its broadest sense - is a journey into the construction of social selves. From this vantage point, however, chocolate presents a dilemma: while Europe might have a culinary dividing line between north and south, chocolate crosses that boundary. Indeed, this has been the case for centuries.

This paper examines the changing role of chocolate in European society, especially in light of the food movement turn to slow, small batch, craft chocolate, as a way to critically analyse relationships of labour and race, gender, and class inequality. The unusual place of chocolate, its ability to cross frontiers and permeate ways of being and experiencing the world, suggests that chocolate can tell us much about not only past lives, but also about how we are right now. The foundations for these transcendent yet contradictory relations lie in the pre-Columbian uses and meanings of cacao, which European colonists then took up in new ways that in fact made tangible and possible fundamental conflicts in class, race, and gender that were intrinsic to colonialism: fantastic wealth built upon extraction and coerced labour; expanding citizenry and consumption, both of which fuelled cravings for social distinctions.

The colonial dilemma was to incorporate new wealth and people, yet maintain social, political, and economic hierarchy; taste and empire were inextricably bound together (Laudan 2013). The confluence of individual consumption, taste, regionalism, and ethnicity is based in making a foreign product "local". Social instability fuelled new uses and meanings of cacao and the widespread adoption of chocolate in the colonial period, developments that have gained even more momentum since. The current state of the chocolate industry has deep roots, yet romantic narratives obscure its understanding, which then makes charting a positive path for a future of chocolate more difficult. Chocolate's ancient and colonial past offers a chance to understand fully the dilemmas and promise of chocolate for today and better plan for a sustainable and palatable future.

\section{Pre-Columbian Cacao: the Place of Chocolate}

To understand the history of chocolate, we begin not necessarily at the beginning of the domestication and first uses of cacao in its homeland in tropical America, but in the places, uses, and time that had most to bear on the eventual adoption of chocolate in Europe. For this discussion, the emphasis is on the intersection 
of taste and labour and how highly distinctive pre-Columbian antecedents had much to do with the ways that Europeans took up the substance, its production, and its growth in popularity over time. Facets that seem like colonial inventions were instead appropriation - Europeans took up the siren call of chocolate in means that amplified what Mesoamericans had already been doing.

Pre-Columbian Mesoamerican regimes of value for cacao invoked class-based authority and extractive production of a commodity. Cacao itself, the processed bean, as well as the tools for making concoctions defined an experience quite separate from other agricultural, consumable products, largely because Mesoamericans consumed cacao in simultaneously discordant and complementary ways: as a ritual offering, as currency, as a flavouring in foods, and as a beverage. The dissonance of the meanings of cacao and chocolate persist today and in this sense, we experience chocolate as Mesoamericans did hundreds of years ago.

\section{MESOAMERICAN TASTES FOR CHOCOLATE: TERROIR, MEANING, AND WEALTH}

Numerous studies have demonstrated the early and widespread use of cacao in Mesoamerica, even as long as 4,000 years (Henderson et al. 2007; Powis et al. 2002). While the northern Amazonian basin of South America may have been the first place of cacao domestication, cacao truly came into its own once it reached Mesoamerica. Cacao cultivation was widespread in Mesoamerica, but intensive cacao production zones were rare due to the fickle nature of the domesticate (Bergmann 1969). By the Late Postclassic period (1200-1520 ACE), the most prolific zones of cacao production were the Izalcos region of today's western El Salvador, the Gulf Coastal region of Tabasco, and the Pacific Coastal region of Soconusco, which the Aztecs conquered to have direct access (López Mendoza 1987; Ruz Lhuiller 1969). This late pre-Columbian pattern shows that although cacao could be accessed in small quantities in many places, the principal supply came from a few; cacao largely came from somewhere else - an export commodity sent from a few principal places to broad swaths of Central America and Mexico.

The idea of terroir, the unique flavours and quality associated with the manner of production and almost ineffable qualities of genetics, climate, soil, and place, also came into play for Mesoamericans. PreColumbian inscriptions describe how people prepared, consumed, and invested meaning in cacao. Maya royal scribes painted texts designating the owner and prescribed contents, oftentimes cacao beverages, of bespoke, "monogrammed" drinking vases. These texts are recipes that included different spices, colorants, and kinds of cacao in various stages of ripeness or processing and from particular regions (Stuart 1988). These preColumbian examples from across Mesoamerica show that distinct recipes were emblematic of a particular place; taste and place designated each other. Cacao consumption was so important that "the distribution of cacao vessels in the Maya Lowlands reflects political and social patterns as well as purely economic ones" (Houston et al. 1989:720). Terroir was alive and well in pre-Columbian Mesoamerica.

For all Meosamericans, cacao was a proper offering in healing rituals, to endorse marriage alliances, and to ensure successful travel. During the Postclassic period, from Yucatan to Oaxaca, celebrants consumed cacao drinks during ceremonies to seal important social contracts and confirm the legitimacy of dynasties (Roys 1972: 106; Smith 1973:3 1; Thompson 1972:6). The ways commoners used cacao just before colonial contact 
never exactly matched elite practices, even though cacao was widely available. This creation of social inequality through cacao production and consumption is an enduring legacy of chocolate.

With a potent history of ritual, cosmological, and high-status associations, cacao was a valued good for thousands of years in pre-Columbian Meosamerica. A fundamental change took place, however, not long before European contact: cacao became the small coin in a monetizing economy. Some have argued that cacao as currency was a Spanish innovation (Feldman 1985:86; Landa et al. 1941:95), but Europeans expressed the great wonder of cacao first as money rather than as a comestible (Benzoni 1565; Champlain 1859:29; Echagoyan 1603; Garcia de Palacio 1985; Gerarde 1597; Martyr 1617; Molina 1571:11r). One of the first European accounts of cacao, by Peter Martyr (1617), extols the usefulness of cacao as money not because it was due to the civilizing influence of Europeans, but because people of the New World were using a highly practical form of currency when the Spanish arrived.

Cacao as a means by which to fix price or exchange value particularly as small coin implies much wider access and ideally consistent and abundant supply. Commoners had the potential to accumulate cacao and ascend in status. To paraphrase Mintz (1985:97), cacao as money must have become a "kingly luxury of commoners" and a "spurious leveller of status." To ignore or minimize this contact-period use of cacao is to overly narrow our understanding so that the dilemmas and contradictory nature of cacao become at a minimum, very hard to explain.

\section{LABOURING IN THE FIELDS OF THE (CACAO) LORD}

The labour for working cacao orchards was mobilized at the level of the household as part of services and obligation to regional dynastic states. Cacao agriculture was not highly gendered. Generally, pre-Columbian scenes of cacao offerings and consumption have both males and females receiving and offering cacao, and cacao is not portrayed as equivalent to maleness or femaleness. Lords administered their dependants and lands, which included peasants who had service and tribute responsibilities in various levels of government and more or less direct access to land as well as tenant farmers who provided goods for individual lords on their private holdings and owed nothing to the larger polity (Evans 1991:64; Lockhart 1992:106). In the preColumbian system of labour obligations, lords demanded services and tribute; cacao production was a way to satisfy the obligations of citizenship, and consuming cacao was a way to display lordly power. Spaniards imposed more European forms within this matrix; they usurped the "territory" of chocolate production.

\section{WHAT IS "ChOCOLATE?"}

It is clear that "chocolate" was one of many pre-Columbian recipes for a cacao beverage (Beliaev et al. 2010, Stuart 2006). "Chocolat" is a Nahua word and has its origin in peripheral Nahua dialects of southern Mesoamerica, including Pipil of the Izalcos colonial Guatemala. Many early accounts identify chocolate as a Guatemalan recipe. Otherwise excellent analyses of the domestication of cacao and its pre-Columbian uses almost always at some point in the narrative make a surprising mistake: they use "cacao" and "chocolate" interchangeably (such as Beliaev et al. 2010, Macri 2005, several chapters in McNeil 2006, Norton 2006). 
For example, the description in the Florentine Codex of cacao beverage making and selling begins with "Tlaquetzalnamacac" translated as "the seller of fine chocolate." While the English translation of Sahagún's sixteenth-century Florentine Codex refers to "chocolate," neither the Spanish nor the Nahuatl original uses the term, but instead refers to a "beverage of cacao" (Sahagún, 1961 [1575-1577]: 93). "Chocolate" was by no means the word or recipe of choice until the sixteenth century at the earliest.

The scene, then, just before Spanish contact is that what may have seemed like a fairly common cultigen - rather like maize - was in reality largely a non-local product, as it was produced in large amounts principally in a few discrete zones. Cacao preparations such as chocolate were iconic of place, designated terroir, while consumers were an increasingly broader class of Mesoamericans. Mesoamerican lords managed cacao cultivation as a part of the functioning of the state and duty of common households. The ability to produce cacao, especially for export, reinforced social hierarchies. The consumption of cacao was not just as a comestible, but also as a commodity money. The added value, as it were, reduplicated the associations of cacao with elite, now monied, classes, while its propagation as common currency also narrowed the separation of those very classes. It tied together people in new ways and destabilized social relations even as the monetized economy aided exchanges in other ways. The distinctive tools and preparation of cacao beverages - the molinillo, the steep-sided cup, and the spouted pot - created a highly distinctive sensorial experience of cacao beverages in Mesoamerican foodways. Which of these features did Europeans embrace, and which did they reject? The answer reveals much about the process of colonialism and how we know chocolate today.

\section{INTRODUCING ChOCOLATE: WeALTH VERSUS TASTE}

For European sensibilities, cacao as a beverage was at first a hard sell - bitter, thick, in short, distasteful to the point of nausea (Benzoni 1565). Norton, however, argued that "the Spanish did not alter chocolate to fit the predilections of their palate ... Europeans in the New World and then the Old World somatized native aesthetic values" (2006:660). In fact, the wholesale European adoption of Mesoamerican chocolate Norton described involved the full complement of Mesoamerican practices and the pace of change in consumption was much faster.

While cacao as a food item was off-putting, the idea of cacao as money had great appeal because sixteenth-century Europe was facing a currency crisis due to a lack of small denominations. Cacao as a commodity money was taken on enthusiastically by Europeans, with the Crown quickly adopting cacao as legal tender for transactions. The use of cacao as a wealth item for Europeans continued well into the eighteenth century, with cacao, solid chocolate, and chocolate-related serving vessels recorded in eighteenth-century colonial British Williamsburg probate records, for example.

How readily did Europeans adopt Mesoamerican tastes? A survey of early colonial cacao beverage recipes shows that early colonial Mesoamerican recipes usually had vanilla and water, and included a variable array of aromatic flavours, such as orejuela (custard apple) and piquant spices, such as chile pepper. Sweetness, by adding honey, occurred, as well (Chart 1). These Mesoamerican colonial recipes also show Europeanization, by the adoption of flavourings such as sesame, almond, and sugar. 
Chart 1. Frequencies of cacao beverage ingredients in Spanish America.

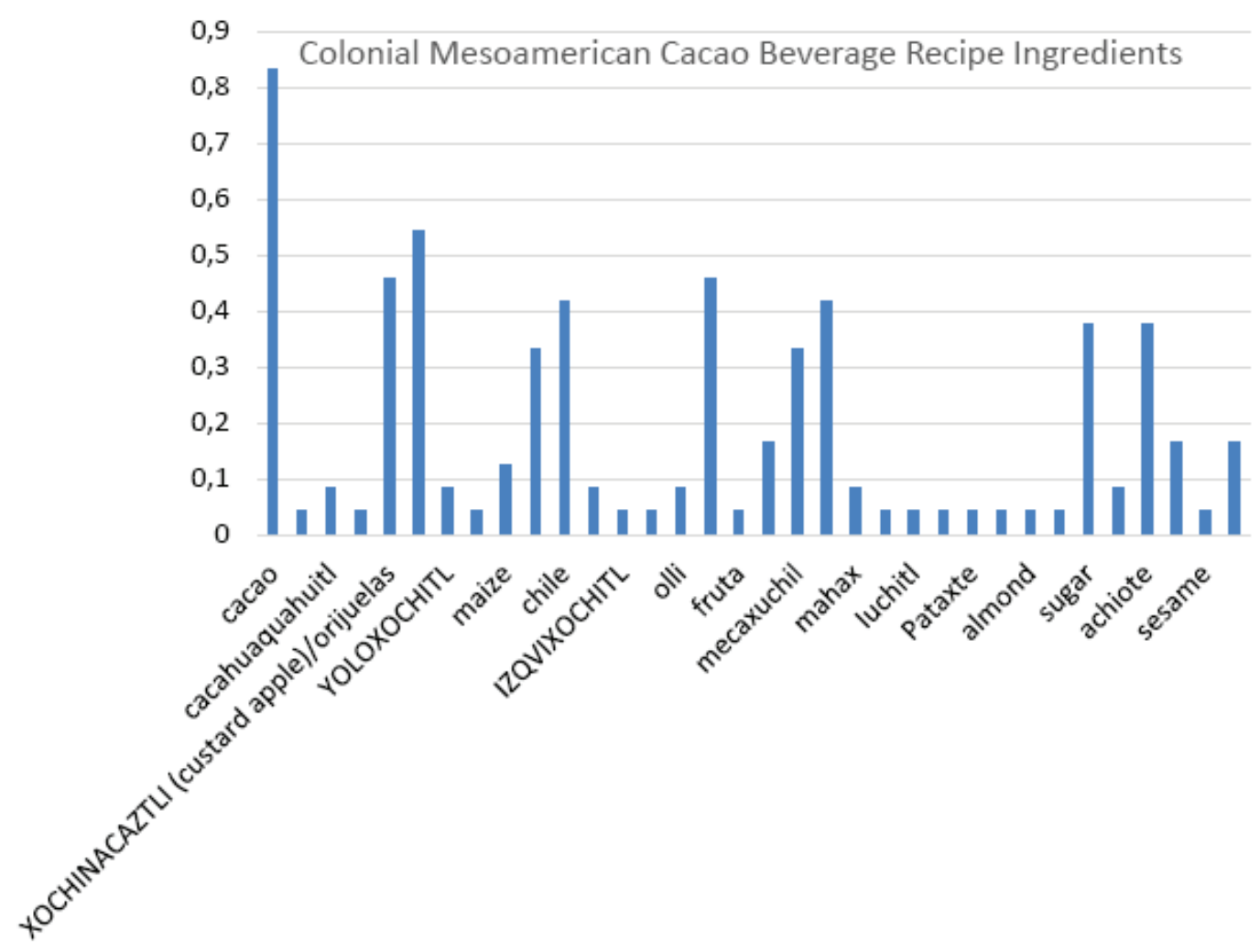

The earliest European recipes in many senses follow the Mesoamerican flavour profile, but by using much more familiar and established flavourants acquired through trade or produced in Europe, such as cinnamon, anise, and pepper (Chart 2). Recipes from American colonies and Europe are all regionally distinct from each other, much as was the case for pre-Columbian Mesoamericans. Europeans truly embraced cacao as a way to define distinct tastes.

Chart 2. Frequencies of colonial European chocolate recipe ingredients.

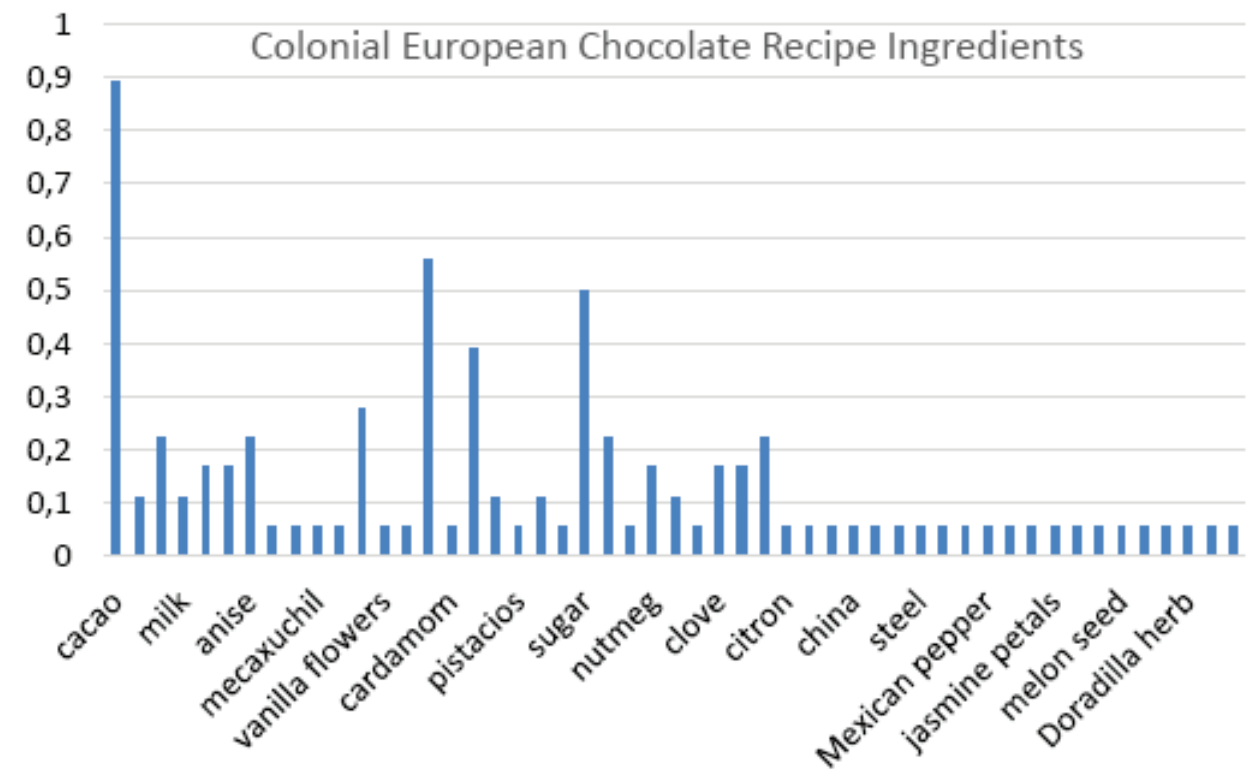


Part and parcel of European embrace of the taste for cacao was the adoption of all the tools of beverage making, but again, translated into different materials. European molinillos and spouted pots were made of metal - copper or silver. The steep-sided cups could be of ceramic, but usually tin glazed maiolica or faience, or later, refined white earthenwares or porcelain. While depictions of Indians consuming cacao beverages show locally-made jícaras (gourd cups) and coarse earthenware vessels (Figures 1 and 2), cups and pots in drawings and paintings of creoles or Europeans are made of ceramic or metal. All of the elements of the Mesoamerican form are present, but the content is distinctly European.

Figure 1. Girolamo Benzoni's sixteenth-century depiction of cacao processing.

Original in the John Carter Brown Library, Brown University.

fra i bojcbu nell bumido, $\mathbb{O}^{\prime}$ non u bastando quetio, ai piantano apprejfo $>n^{\prime}$ albero, ilquale gli è juperio $r$, $\forall$ come comincia a crefcere gli raddoppiano las cima di forte, cbe quand o é grande, to chopre, $\theta$ cofil'nno cont altro fi fanno onbra, di modo che'l sole non gli did noia alcuna.

Albero che produce il cacanate, \& come gl'Indiani di due legni cauanó fuoco.

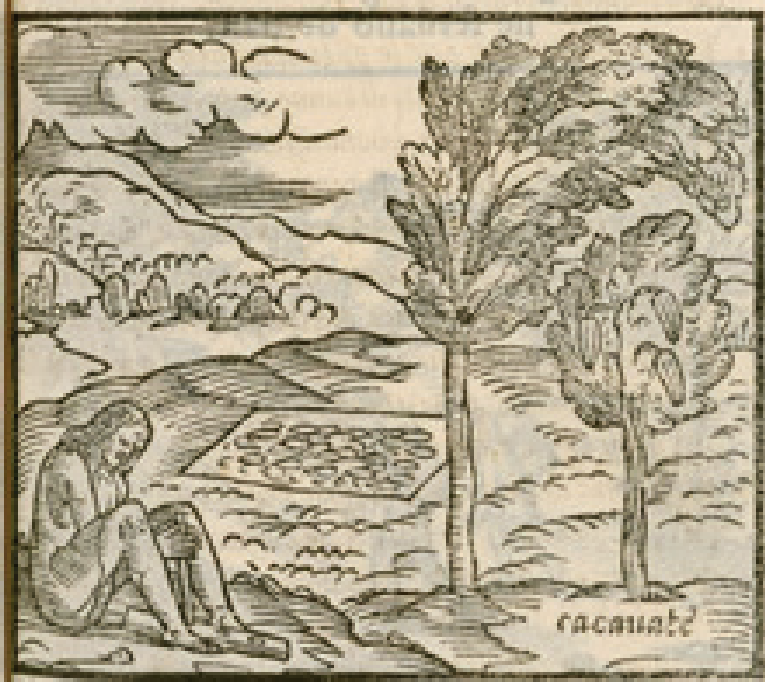

If fins frutto d a modo di mandorke, dv ndfecin cer
Figure 2. Illustrations of the American, Indian associations of chocolate in Philippe Dufour's treatise on chocolate. Original in the John Carter Brown Library, Brown University.

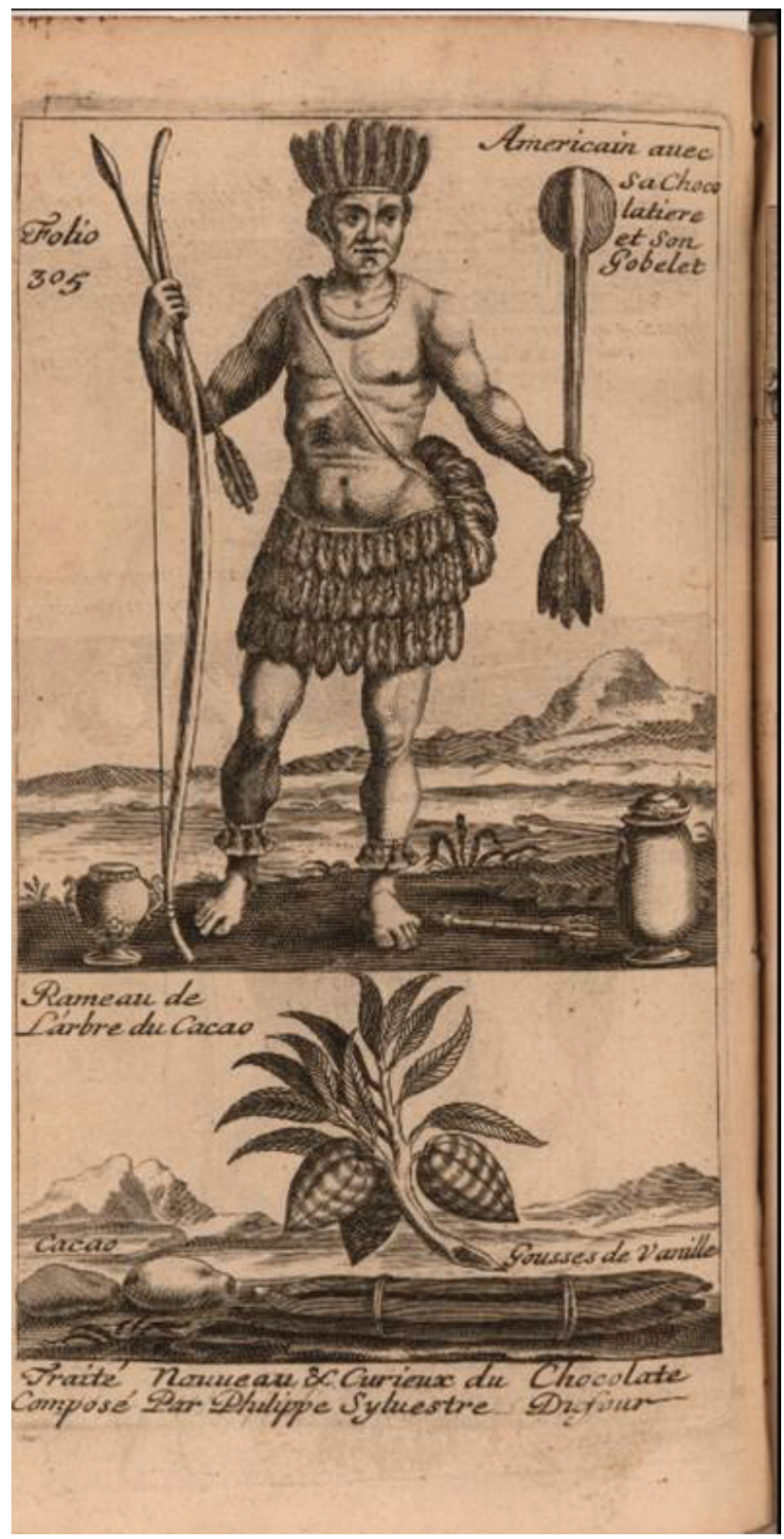




\section{EUROPE AND CHOCOLATE: COlONIAL DESIRE}

Where in all of this, is chocolate? A letter written by the Jesuit Pedro de Morales in 1579 describes chocolate as a blend of cacao and achiote (Mariscal Haz 2000:57). "Achiote" is known in English as "annatto," and gives a red hue to foods. Morales stated explicitly that this drink "was invented in Guatemala." Most early sources link chocolate and Guatemala, including Henry Stubbe, the British King's Royal Physician, who wrote that "chocolate has been eternally drunk in Guatemala (as ale is to England)" (1662:3). Stubbe (1667) endeavoured to "take care, that England know it, and have the benefit thereof" and made clear that all classes, sexes, and temperaments could benefit from chocolate if taken in the correct way, tailored to a person's constitution. He argued that:

...this is the most pretious Drink of Drinks; this excells all others in advantages for our health, which either Time by a long succession of years, or encrease of Luxury and Pleasure to this day hath acquainted us with: because neither in the Chocolata itself being made into a Drink, no nor int any Ingredient thereof, is there any thing wanting, that is necessary for the Life, or delight of Man, and so to invite him to use it. (Stubbe 1667:95-100)

Relative amounts of Spanish tribute quotas leave no doubt where the homeland of the special recipe of chocolate was: the Izalcos region of today's western El Salvador (Ciudad Real 1973; Fowler 1987, 1989, 2006; García de Palacio 1985[1576-1587]). From the mid-sixteenth to the early seventeenth century, about 1.2 billion cacao beans per year were exported from Acajutla, the port of the Izalcos, and tribute levels from this region were at least triple those of other cacao-producing zones (Escalante 1992(1):56). The word "chocolate" first appears in central Mexican and Spanish documents just as the Izalcos region reaches its peak of production and the price of cacao reaches an astronomical all-time high around 1580. The word for a special recipe for a cacao drink from the region of astronomical cacao production started to become the name for the commodity when it became a source of fantastic wealth. As the wealth grew, the word spread. Europeans learned to like chocolate because of their material dependence on Indians, but this was not because it was a curious food or drink, but because it was an engine of commerce.

\section{COLONIAL LABOUR: SERVITUde AND SLAVERY}

Another way that Europeans adopted cacao wholesale was in management of production. How was this astronomical amount of cacao produced? Did colonization usher in fundamentally different forms of labour? The Spanish institution of the encomienda can be seen as much like pre-Columbian forms of tribute duty. An encomienda is a reward by the Spanish crown of labour and tribute in a region to colonists of merit such as conquistadors. Some of the first major exports of cacao happen at about the time the Izalcos encomienda was awarded, and it became one of the richest encomiendas in all of the Indies.

The success of cacao commerce created a nearly unrestrained frenzy for colonial control over every last bean. In this regard, Spanish coercive policies and illegal abuse were a departure from pre-Columbian antecedents. Indigenous cacao producers were held hostage, prevented from buying products freely, nor did they produce basic, everyday items. Encomenderos had monopolies on basic foodstuffs, which sold for up to 
ten times their typical value (Escalante 1992(1):215). Encomenderos were accused of sending slaves to enter into houses as well as orchards and take cacao by force, torturing, and incarcerating people suspected of hiding cacao reserves (Escalante 1992(1):259). Beyond official tribute, the Spaniards stole more, and recaptured even more by selling products at inflated prices.

The Spanish assessed tribute duties of Izalcos-region encomiendas by married Indian households and by the amount of land and cacao trees the individual had rights to. The household members decided how and who worked in the cacao orchards, as was done before colonization. Colonial cacao orchard labour was a mix of chattel slavery (in that indigenous residents were held hostage) and wage labour, paid by the native families. From 1542-1580, even after the New Laws prohibiting native enslavement, the conditions for Izalcos cacao labour became worse and worse. Labour shortages due to disease were compensated for by increasing numbers of migrant wage labourers, with only $10-20 \%$ of original indigenous families remaining in some towns. So, the Spanish siphoned off the skills, knowledge, and experience of indigenous residents.

\section{African SLAVERY, DARKNESS, AND HEALTH}

After the initial, long sixteenth-century reliance on encomienda-coerced labour and rapid shifts to native-controlled wage labour, market dominance in cacao production shifted to new regions free of the entanglements of a long heritage of indigenous production: today's Costa Rica, Venezuela, and Ecuador (McLeod 2008). These regions did not have the same skilled, knowledgeable population; the orchards were on privately-owned land and worked by enslaved Africans. This change was met by clamoring resistance on the part of colonial Guatemalans, who saw their wealth slipping away. They phrased their complaints in terms of health and quality. Residents of Guatemala made repeated legal claims that pleaded for limitations on the export of cacao of Guayaquil and other centres because it was of poor quality (Escalante 1992). Complaints stated that low-grade cacao was flooding the market and driving down prices (which was, in fact, true, at least in terms of price). Many complaints also argued that this low-quality product made people sick or at least did not have the full health benefits of high quality cacao (Escalante 1992). These complaints flesh out colonial dilemmas regarding the benefits of cacao and its connection to morality.

This move towards African slavery was also accompanied by a more consistent association of "chocolate" with a cacao drink that was dark, foamy, and potentially sinful or decadent (León Pinelo 1636, Figure 3). The overall trend during the colonial period is for chocolate to become increasingly, even exclusively, associated with sweet, dark, rich foods and drinks. The number of ingredients in recipes also tends to become fewer over time, such that cacao, divorced from the vanilla that almost always co-occurred with it, becomes a single, highly sweetened flavour. African enslavement, sugar, and tastes for sweetness mutually reinforced each other, creating a new foodways regime that was predicated upon capitalism; chocolate tastes and production were part of this nexus (Mintz 1985). While pre-Columbian evidence demonstrates that sweetened forms of cacao concoctions existed long before Europeans found chocolate (and in fact, perhaps Europeans learned to like the sweetened versions by tasting them first in Mesoamerica), indigenous Mesoamericans did not exclusively associate chocolate with darkness and sweetness. That "chocolate" was rich, dark, bitter, and sweet related 


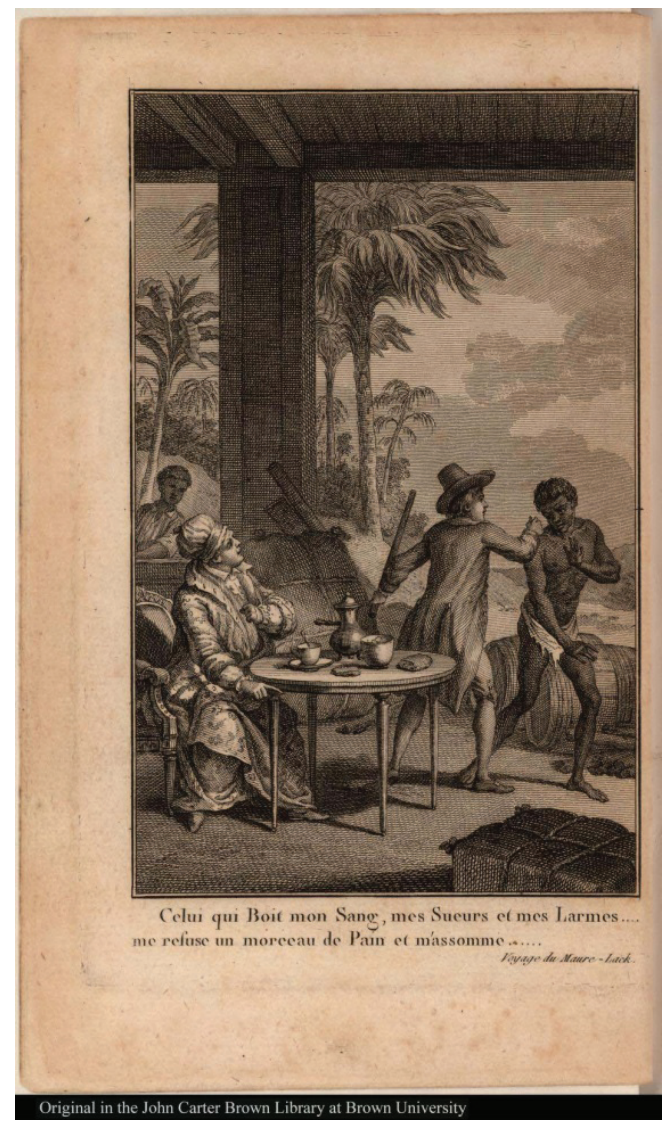

Figure 3. Slavery and chocolate.

Image from "Le More-lack, ou Essai sur les moyens les plus doux \& les plus équitables d'abolir la traite \& l'esclavage des nègres d'Afrique, ...", London, 1789.

Figure 4. From the Lewis Walpole Collection.

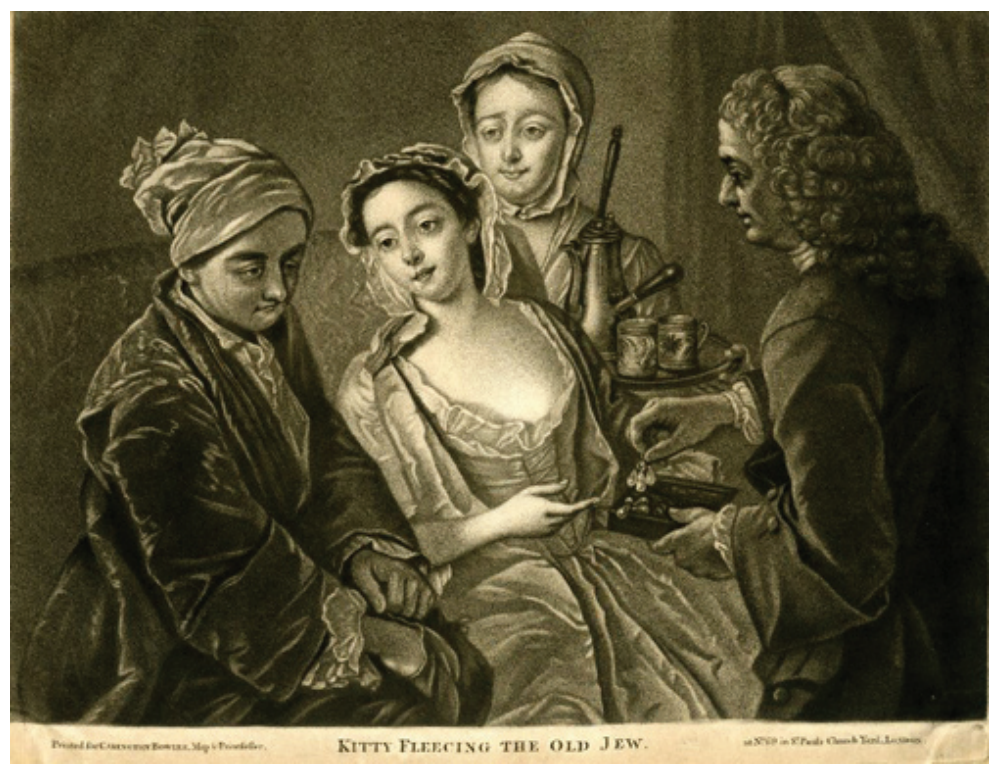

directly to its connection to racialized circumstances of labour; that it was wealth, but secured at a moral and social cost. Chocolate could mark distinction in taste, quite literally, yet also keep that colonial, foreign, tropical product relegated to a comprehensible and restrained place.

\section{ENGENDERING CHOCOLATE}

One of the most dramatic shifts in the semantics of chocolate, and probably intimately connected with its shift towards sweetness, is its feminization. While pre-Columbian antecedents suggest a gendering that is not exactly male or female, colonial narratives strongly connect chocolate and women (Figure 4). As mentioned above, a 1578 allegorical arch personified Guatemala as a woman holding a cacao branch. In fact, chocolate was seen to particularly affect women, transforming their beauty and fertility, in some cases dangerously so; women would do anything, even murder a Bishop, for chocolate (Stubbe 1662).

\section{Enslaved Labour, Globalization of Cacao Production, Shifting Tastes}

The historical context and analysis of labour in cacao farming and chocolate production shows a critical reliance on coerced labour in the forms of chattel slavery and indentured servitude, precedents for the complex present-day labour conditions in cacao and chocolate that include the devaluation of labour, forced labour, and the worst forms of child labour. As described above, with the collapse of the encomienda system that usurped indigenous labour and land, Europeans sought a new means to meet increasing Old World demand for exotic New World cash crops. From roughly 1500 to 1900, between 10 and 15 million enslaved Africans survived 
forced transport across the Atlantic and began working under chattel slavery, treated as property or what Mintz (1985) has called "false commodities." Approximately 60\% of enslaved Africans arrived in the Caribbean, $30 \%$ in Brazil, and less than 10\% in British North America (Gomez 2005).

Mintz writes: "England fought the most, conquered the most colonies, imported the most slaves, and went furthest and fastest in creating a plantation system. The most important product of the system was sugar" (1985: 38). Indeed, lucrative commodities like sugar (and rum), coffee, tobacco, cotton, and cacao required intensive, skilled labour, working under frequently strenuous conditions. The life expectancy of many of the enslaved was very low, especially in sugar production. Upon arrival, enslaved sugar labourers were expected to survive only 7 to 8 years.

The triangular Atlantic trade was the site of enormous wealth generation and botanical, demographic, and cultural change. Cacao, native to South America, was spread throughout the New World, Southeast Asia, and West and Central Africa for cultivation. Imperial powers came to rely on goods produced by enslaved labourers, implicating slavery directly in the development of capitalism (Williams 1994). The crown jewels goods-producing colonies controlled by European powers (for France, Saint-Domingue, now Haiti; for Spain, Cuba; Great Britain, Jamaica; Portugal, Brazil and eventually São Tomé and Príncipe; and the United States, The South) - became sites for the extraction of wealth. By way of example, in the case of France and SaintDomingue, by 1789, the colony exported nearly half of the world's coffee and sugar (more than Jamaica, Cuba, and Brazil combined) and provided France with $40 \%$ of the value of all French trade. More than 1 million of the 25 million inhabitants of France depended directly on the slave trade for their livelihood (Davis 2007).

While much of the forced exchange of lives and labor took place between Africa and Latin America, both Europe and North America were thoroughly implicated in this trade system. Writing at Oxford in 1839, the prominent British colonial administrator Herman Merivale explains:

We speak of the blood-cemented fabric of the prosperity of New Orleans or the Havanna: let us look at home. What raised Liverpool and Manchester from provincial towns to gigantic cities? What maintains now their ever active industry and their rapid accumulation of wealth? The exchange of their produce with that raised by the American slaves; and their present opulence is as really owing to the toil and suffering of the negro, as if his hands had excavated their docks and fabricated their steam-engines...

Every trader who carries on commerce with those countries, from the great house which lends its name and funds to support the credit of the American Bank, down to the Birmingham merchant who makes a shipment of shackles to Cuba or the coast of Africa, is in his own way an upholder of slavery: and I do not see how any consumer who drinks coffee or wears cotton can escape from the same sweeping charge. (1861:302)

Opposition to Atlantic chattel slavery always existed and, as enslavement became less financially viable and morally tolerated, abolition came gradually and slowly over a period of approximately 100 years. ${ }^{4} \mathrm{Abolition}$

4 The Haitian Revolution (1791-1804) culminated in the end of slavery and formation of the Republic of Haiti, though the French demanded crippling reparations for their financial losses. Then, in 1834, the British Slavery Abolition act abolished slavery throughout most of the British Empire; France and Denmark followed more than a decade later. The United States abolished slavery with the thirteenth amendment to its Constitution in 1865 . Cuba and Brazil followed much later, with abolition in 1886 and 1888 , respectively. 
frequently involved a continued extraction of wealth, with periods of indentured servitude and schemes to compensate former slave owners for their loss of property. Only rarely was abolition accompanied by reparations for the formerly enslaved, and poverty and landlessness remain serious problems among the descendants of enslaved people throughout cash crop producing regions today.

Once the system of slavery came apart at the seams, European powers worked to increase cacao production in other places with suitable climates and inexpensive labour sources, such as São Tomé and Príncipe, West Africa's Gold Coast, and Indonesia. Exploitative labour practices continued in cacao and sugar production post-abolition. In the early 1900s, slavery was uncovered on cacao plantations in Fernando Pó (now known as Bioko) and in Cameroon, both on German and on Duala elite plantations (Clarence-Smith 2000). The use of enslaved people from Angola was common on Portuguese plantations on the islands of São Tomé and Principe from the 1880s and continued there well into the mid-1900s (Satre 2005). Indentured servitude of South and East Asians was also common throughout the colonial world.

Cultural contact through colonial enslavement contributed directly to the shift in culture and taste among Europeans in relation to chocolate. Mintz explains the challenge of understanding the scale of these changes:

The first sweetened cup of hot tea to be drunk by an English worker was a significant historical event, because it prefigured the transformation of an entire society, a total remaking of its economic and social basis. We must struggle to understand fully the consequences of that and kindred events, for upon them was erected an entirely different conception of the relationship between producers and consumers, of the meaning of work, of the definition of self, of the nature of things. What commodities are, and what commodities mean, would thereafter be forever different. And for that same reason, what persons are, and what being a person means, changed accordingly. In understanding the relationship between commodity and person, we unearth anew the history of ourselves. (1985: 214)

These societal shifts in meaning were fundamentally linked to the dislocation of production and consumption in commodity markets, and the transformation of the relationship between producers and consumers.

Gikandi, too, argues in Slavery and the Culture of Taste (2011) that slavery was in fact key to white selffashioning of identity, as evidenced in art, literature, and personal diaries from Europe and the United States. While slavery was treated as a taint to good taste and at times actively kept out of the narrative of high culture, posing in portraits with an enslaved person became part of a popular genre and was seen as representative of excellent taste and access to vast fortunes. Simultaneously, enslaved people were dehumanized to justify their absence from narratives and African-derived cultural elements were appropriated by whites and treated as though they were European-derived. Thus, the power dynamics of race and culture came to be heavily inflected by the history of enslavement.

Robertson similarly considers these and related power dynamics in Chocolate, Women, and Empire. She writes: "In the mythology of chocolate, the power relations of production and consumption are subsumed by a more attractive narrative of exotic peoples and their surroundings...chocolate seems to generate a particular type of history writing... one which delves into the realms of fantasy and romance" (2009: 85-86). Chocolate 
conquered the tastes of Europeans throughout the colonial period, spread by monks and nuns, among noble families, and indicative of access to the rich resources of the exotic New World, and was simultaneously a key player in the hybridization of genetics, language, culture and flavour. Robertson continues to explain that because chocolate was romantically constructed as "luxurious, hedonistic and sensual" (2009: 3) due to its perceived relationship with affluence, a powerful trope emerged linking chocolate and sex in the European imagination. This trope was also linked to race, as a result of chocolate's so-called "exotic" origins and the reliance upon the labour of people of colour for its cultivation.

\section{SOCIAL INEQUALITY AND THE POPULARIZATION OF CHOCOLATE}

A long-term perspective on the changing culture of chocolate consumption shows a trajectory of increasing permeation of chocolate into European foods and regionalization of tastes in chocolate recipes, such as the Hungarian chocolate pastry tradition of Rigó Jancsi (chocolate sponge cake with chocolate cream filling). Over time, this development of local taste has been undermined by industrial manufacture of chocolate. Cacao, a non-European food, an American cultigen, is thus made "local" through processing. The resulting marketing claims all involve choices that set consumers' lives apart from those who produced it. It is a food ideology that makes the strange familiar (chocolate as a common, everyday food), and what should be familiar, or transparent, strange (how chocolate comes to be).

With the industrialization of food, particularly with mechanization, retailing, and transportation changes in the 1800s, chocolate underwent an enormous change. It was no longer an elite, expensive product primarily consumed as a beverage, but instead an inexpensive cocoa powder to be drunk or low-cacao-content chocolate bar to be consumed as a food by elite and non-elite alike. Companies like Lindt, Nestlé, Cadbury, Hershey's, and Mars, relative early arrivals to the chocolate manufacturing game, implemented major changes in industrial chocolate production to support the ability to scale (Coe and Coe 2013). They aimed to create uniform products by blending beans and standardizing formulations that would taste the same each time consumers purchased them. This represented a stark contrast to historical chocolate flavour experiences, which, as shown above, at times allowed consumers to specify the origin of the chocolate of their preference in great detail. Large chocolate manufacturers also sought means to regulate production against adulteration and to promote longer shelf life of products. Additionally, they found it increasingly important to control the supply chain to avoid interruptions in production. ${ }^{5}$ Over time, the industry shifted dramatically, and large chocolate manufacturers became the producers of the majority of the world's chocolate.

Cacao cultivation began in the late 1800s on the Gold Coast (what would become Ghana), but expanded in earnest in the 1900s, partly due to divestment from São Tomé and Príncipe by British chocolate firms following the scandals uncovering enslaved labour there (Clarence-Smith 2000, Satre 2005). The intersectional relation of race, gender, and class in chocolate became further complicated when women were put to work in the Quaker owned factories in imagined utopian villages like Bourneville and York, where morality and separation

5 E.g. Milton Hershey, who already carefully controlled his milk supply, purchased land for sugar production in Cuba in the early 1900 s to ascertain access to the commodity even in the event of a world war, going so far as to construct a local railway system to support it. 
of the sexes was treated as paramount to the preservation of civilized society. Contemporary cacao farming, too, is highly gendered; most late colonial and contemporary farmers have historically been depicted as men, though it is well documented that women and children contribute a significant amount of labour to cultivation of the crop. Advertisements, both historical and contemporary, regularly gender and racialize chocolate, as described in detail in Robertson (2009) and Leissle (2012).

With these changes in production came massive changes in flavour and nutritional content, as well, such that industrially manufactured chocolate and candy typify what scholars now call "ultraprocessed foods." Seeking economy, manufacturers began to substitute artificial ingredients like vanillin for vanilla and vegetable oil for cocoa butter and to otherwise alter the taste, texture, and experience of eating chocolate. As a result, the processed, the artificial, and the fake came to be commonplace throughout the twentieth century, and even expected as part of chocolate flavour (Kawash 2013). Sugar and fat, both key components of chocolate that at different times were celebrated or vilified through advertising, powerful lobbies, and government policy, became linked with the prevailing social mores.

Today, Europe is the world's biggest processor of cacao (60\% of the world total) as well as the largest per capita consumer of chocolate (50\% of the world total) (ICCO 2013). Eighteen of the top 20 chocolate consuming nations are in Europe. The average British citizen will consume $7.5 \mathrm{~kg}$ (16.5 lbs) of chocolate per year, the average Austrian $7.8 \mathrm{~kg}$ (17.25 lbs), and the average Swiss $9 \mathrm{~kg}$ (20 lbs) (Nieburg 2014). Industrial chocolate products, such as the popular Hungarian Túró Rudi and Túró Csoki are higher in sugar and less complex in flavour when compared to the fine Hungarian bean to bar craft chocolate made by makers such as Szántó Tibor and Rózsavölgyi Csokoládé and the fine confections of chocolatier chocoMe. Today's largest companies, colloquially known as the "Big Five," are Nestlé, Mars, Cadbury (owned by Kraft), Hershey's, and Ferrero, three of which have European roots, and all of which seek global consumer brand loyalty.

To support increasing demand for chocolate in the 1960s and 1970s, following independence from Britain and France, cacao production increased heavily in the newly formed states of Ghana and Côte d'Ivoire. While production has at times since suffered due to government instability or civil war in these nations, they remain the top two national producers worldwide, followed by Indonesia. The West and Central African nations of Côte d'Ivoire, Ghana, Nigeria, and Cameroon collectively produce approximately $70 \%$ of the world's cacao today. The longstanding disjuncture between producers and consumers is highlighted by the consumption of producers: even though Africa is world's biggest producer of cacao, it is also the smallest per capita consumer of chocolate (3\% of the world total) (ICCO 2013). Though cacao was less suited to large-scale plantation production than crops like sugar or tea, the long history and ongoing problem of exploitative labour practices have largely been forgotten, except by those consumers who actively seek to avoid them in the present day.

The demographics of cacao production in these African countries are striking. The vast majority of cacao production takes place on 2 million small, independent family farms ranging in size from 2 to 4 hectares and characterized by complex systems of land ownership and landlessness. Depending on the location, each hectare produces only 300 to 400 kilograms of cacao beans annually, considerably less than many Latin American or South-east Asian farms, due to a number of factors including aging trees, disease, lack of funds for fertilizers, 
and limited education. The median age of farmers is approximately 50 and, while a typical household head is male, women and children contribute a great deal of labour (World Cocoa Foundation 2014). One 2011 study showed that the average daily income per capita for a Ghanaian cacao farming household is below \$0.30 USD. Due to these factors, when surveyed, less than one-quarter of cacao farmers said that they would recommend that their children go into cacao farming (Hainmueller et al. 2011). At present, these farmers collectively produce 2.8 million metric tons of cacao per year.

Farmers in West and Central Africa face many critical challenges; perhaps the most well-known outside of the region is that of eliminating the worst forms of child labour. Multiple studies have been conducted by independent organizations in recent years to track the problem (Berlan 2011). ${ }^{6}$ The issue of labour abuses in cacao cultivation has been publicized widely as a result of journalistic and consumer advocacy, with a number of documentaries made and consumer campaigns staged since evidence of child trafficking and slavery on cacao farms was brought to public knowledge in the late 1990s. It is undeniable that some West African children are trafficked and forced to labour in dangerous conditions with no or little pay on cacao farms. These numbers are difficult to track, but abuses are serious. It is equally important not to hyperbolize through reliance on tropes denigrating to West African culture, as is often the case in advocacy efforts. The problematic result of much of this advocacy is a persistent exploiter-exploited binary stereotype in relation to West African cacao and limited practical improvement of farmer livelihoods and access to social services.

\section{The RISE OF COMPASSIONATE ChOCOlATE CONSUMERISM}

Responses to labour problems in the cacao-chocolate supply chain have included the Harkin-Engel Protocol; non-governmental organization investments, program development, and research; Corporate Social Responsibility standards; consumer awareness campaigns and boycotts; legislation in African countries; and legal action abroad (e.g. the 2010 California Transparency in Supply Chains Act and an ongoing lawsuit in California to determine if Nestle, Archer Daniels Midland, and Cargill should be held responsible for child enslavement on farms from which they sourced cacao in 1990s). It remains debatable if the Harkin-Engel Protocol of 2001, a voluntary international agreement aimed at ending some of the worst forms of child labour, has had a significant effect in stemming the problem.

In an attempt to address labour abuses and increase farmer yields to ensure a steady cacao supply chain, a variety of certification schemes (e.g. Fair Trade, Rainforest Alliance, UTZ Certified, IMO Fair For Life) have proliferated in cacao sourcing, attracting significant consumer interest. As McCabe shows, through marketing

6 Most notable is a series of studies from Tulane University from the project "Oversight of Public and Private Initiatives to Eliminate the Worst Forms of Child Labor in the Cocoa Sector in Côte d'Ivoire and Ghana," the findings of which demonstrate mixed results at best from cocoa industry attempts to remediate the worst forms of child labour, with numbers of children involved shown to be increasing in 2013/14 survey data (Tulane University 2015). The series also confirms that many children work on cacao farms in Africa not as forced labourers but as parts of family labour pools. It is when their work tasks constitute hazardous labour - such as transporting heavy loads, pesticide and fertilizer application, or the use of sharp tools like machetes - or interferes with physical and educational development that this breaches international agreement. Many children working in these conditions receive no training or protective gear. Hazardous labour can result in injury and sickness, musculoskeletal disorders, sprains, lacerations, fractures, eye injuries, rashes, and respiratory irritation. Long-term negative health effects are likely. In addition, some research shows that hard labour can developmentally delay children (Berlan 2011) 
and consumer awareness around labour abuses in cacao cultivation and fair trade certifications, fine chocolate "was transformed from deterritorialized product perceived to come from chocolatiers in West European countries like Belgium and France to reterritorialized product connected to cocoa bean growers in tropical regions of the world" (2015:54). The fine chocolate market exhibits what she calls "resistance" - a form of agency - distributed in a fine chocolate assemblage of connoisseurs, products, producers, and institutional discourse, and characterized by a group force or momentum to link sensual enjoyment with ethical concern.

Yet, dissenting voices on certification are gaining in volume, with contradictions in the movement ever more apparent. The primary argument made by fair trade labeling critics is that the movement does more to make wealthy consumers feel good than to significantly counter poverty in the developing world. For example, according to some calculations, an American consumer's dollar paid for a fair trade product results in only 3 cents more paid to a developing country farmer than a dollar paid for an uncertified product (Sylla 2014). The rhetorical claims of fair trade, therefore, are strikingly different than the results of its practice. In addition, emerging arguments suggest that certification stifles innovation by prioritizing consensus among participating companies and incentivizing only baseline standards adherence, ultimately becoming part of the problem rather than part of the solution (Poynton 2015). Direct trade schemes and transparency based on companies' stated values are increasingly championed as important methods to transform and verify supply chains, though evidence of their superior effectiveness in cacao sourcing has not been thoroughly documented or analysed.

Still more, chocolate occupies an uneasy place in European diets today, especially in light of growing rates of obesity and recent "junk food taxes" that target foods high in salt, sugar, or fat (Daley 2013). While industrially manufactured chocolate usually falls into the category of candy, much of the fine chocolate on the market is sold as high in antioxidants and otherwise of potential benefit to consumer health. This complex link between chocolate and morality is boldly apparent in the attempts by large chocolate manufacturers to corner the Asian market and its potential billions of customers. These attempts are characterized by a pervasive Orientalism that aims to conquer the hearts and minds of innocent Asian consumers by attracting them to Western sin (e.g. Allen 2010).

\section{A RETURn TO Fine Flavour}

A serious, regrettable loss of agrobiodiversity linked to flavour also occurred as chocolate manufacturers prioritized sourcing of more inexpensive, bulk cacao over fine cacao. ${ }^{7}$ In the industry, bulk cacao is generally understood to produce with higher yield and to be more disease resistant, though this is often coupled with a

7 The difference between the two, which remains controversial as a result of our still emerging comprehension of cacao genetics, is defined by the International Cocoa Organization as follows:The world cacao market distinguishes between two broad categories of cacao beans: "fine or flavour" cacao beans, and "bulk" or "ordinary" cacao beans. As a general concept, fine or flavour cacao beans are produced from Criollo or Trinitario cacao-tree varieties, while bulk cacao beans come from Forastero trees. There are, however, known exceptions to this generalization. Nacional trees in Ecuador, considered to be Forastero-type trees, produce fine or flavour cacao. On the other hand, Cameroonian cacao beans are produced from Trinitario-type trees and their cacao powder has a distinct and sought-after red colour. However, these beans are classified as bulk cacao beans. (ICCO 2015)

Arguably the most popular strain right now, $\mathrm{CCN}-51$, has been simultaneously heralded by Big Chocolate as a solution to the world's growing needs for more cocoa, and villainized among fine flavour advocates. 
greater labour requirement. It is sold at a commodity price per ton and makes up between 93 and $95 \%$ of global production today. However, connoisseurs note that bulk cacao most often has inferior flavour and aromatic qualities when compared to fine cacao. Fine cacao, on the other hand, is often believed to produce lower yields and be more susceptible to disease, though emerging research suggests that this is an oversimplification. In general, it is sold at a higher price per ton based on perceived quality of beans, suggesting the potential to improve farmer livelihoods. Its fine flavour status is determined by quality assessment of the beans, especially in relation to genetics, origin, and post-harvest practices (though lack of standardization leaves much to be desired). At present, fine cacao makes up only 5 to $7 \%$ of global production, a stark difference from the early 1900s, when it was produced in virtually the same quantity as bulk cacao.

In response to the perceived loss of flavour and quality in industrially manufactured chocolate, beginning in the 1970s and 1980s, an increasing number of bean to bar chocolate makers made a return to small scale manufacturing, often using vintage equipment and single origin fine cacao. Companies like Valrhona, Bonnat, Cluizel (France), Domori (Italy), El Rey (Venezuela), and Scharffen Berger (based in the United States, and now owned by Hershey's) attracted high end consumer interest by marketing their products as haute cuisine, crafted by skilled artisans with a focus on fine flavour. This reflected a return to interest in terroir, or the sense of a place, in chocolate. This renewed consumer interest in fine flavour, combined with increased desire to avoid the highly publicized problem of child slavery in chocolate (with all the requisite challenges in understanding the issue) proved foundational to the success of the growing interest in the bean to bar, fine chocolate market (Eber and Williams 2012; Rosenblum 2005) .

Such social production of taste has also informed the self-fashioning of European identity in relation to chocolate, as demonstrated by Terrio in her ethnographic account of research among French chocolatiers. She writes that in the mid-1900s: "chocolatiers were a people without a history because of their ambiguous role in a postwar history whose master narrative was constructed around the themes of modernization and professionalization" (2000:11). As French chocolatiers grappled with the formalization of definitions of craft work, associations, and training models, they also engaged in the production of a new notion of good taste focused on vintage, grand cru dark chocolates. Together with craft leaders, artisanal families, taste makers, CEOs, advertising executives, government authorities, and consumers, they confronted historical notions of French identity in the late capitalist age and forged a new French chocolate identity based around the perceived superiority of locally produced, artisanal chocolate over seemingly anonymous industrially manufactured chocolate.

Terrio's research carefully tracks issues of gender, familial heritage, and authentic national identity that are complemented by Robertson's (2009) focus on gender, race, class, and the power relations of production. This allows us to consider the conflict between artisanal, craft production that is local and specific in the increasingly generalized, delocalized European Union food system. Chocolate, too, is a part of the broadly defined global food movement, founded on several influential ideologies. As Winson details, general tenets of the food movement include the beliefs that: consumers have rights which must be fought for rather than assumed; human and environmental health go hand in hand; there is no such thing as an average consumer; 
what matters is not just "what" is eaten, but "how" it is produced and distributed; and policies can be changed for the better, but this requires imagination, coalitions, and focused effort. Winson explains:

In the process of [consuming food and drink] we take them inside our very bodies, a fact that gives them special significance denied such 'externally' consumed commodities as refrigerators,

automobiles, house paint or television sets. Moreover, unlike many other goods that we produce and consume in capitalist society, food is an essential commodity: we literally cannot live without it (although this is not to say that all of the processed food products for sale today are essential). (1992:4)

The consumption of food is thus fraught with global significance.

Arising from the early interest in single origin, bean to bar chocolate came a turn to slow, small- or microbatch craft chocolate in the late 1990s, with a heavy focus on batch production, flavour, quality, and perceived ethical sourcing of raw ingredients. ${ }^{8}$ Since the mid-2000s, when the number of companies hovered at around half a dozen in North America, a proliferation of craft chocolate makers has occurred, with over 150 companies now operating in North America (Brelinski 2015), and an estimated 70 companies in Europe (Bernardini 2015). Rózsavölgyi Csokoládé, a Budapest-based company, is one example of a local Hungarian craft chocolate maker. Started in 2004 by a husband and wife team, the company now has a retail shop in Budapest's art district, and a small but expanding factory where the chocolate is made. The owners carefully source cacao from respected operations, even going so far as to highlight the post-harvest practices of the growers and to specify which genetic variety comes from which country of origin in their marketing materials. Their single origin dark chocolate bars are made in elaborate moulds designed to look like a traditional Hungarian tile and wrapped in ornate, colourful paper. Over the years, Rózsavölgyi Csokoládé products have won several awards from the UK-based Academy of Chocolate and Guild of Fine Food and have been finalists in the International Chocolate Awards competition. The company is explicit in its mission to meld traditional and modern, craft and fine art:

Chocolate as a material is particularly inspiring. We at Rózsavölgyi Csokoládé use traditional processes and pure ingredients to achieve the most natural flavours and apply detailed yet contemporary designs to create a memorable experience - a true piece of art...Old Hungarian shapes and patterns blend in with new creations; traditional chocolate making with a modern view. It brings consistency without compromising quality. (Rózsavölgyi Csokoládé 2015)

This chocolate is packaged and sold in ways that indicate its localness, while also indicating knowledge of the foreign conditions of production.

There are a number of potential positive impacts of the craft chocolate movement that emerging research suggests. Often, farmers are paid significant premiums for fine cacao that has been carefully harvested, fermented, and dried and, when carefully sourced, this cacao is often grown without the heavy use of synthetic chemicals and under better labour conditions than most bulk cacao. In some cases, farmers and chocolate makers work together and educate one another on best practices. A small number of companies (such as

8 While no standard definition of craft chocolate exists, it generally refers to chocolate made from scratch, starting with the unroasted cacao bean in a company's own facilities using traditional methods of chocolate making (roasting, winnowing, tempering, tempering and depositing chocolate). Craft chocolate companies also typically produce at a small scale, processing significantly less than 200 metric tons of cacao beans per year. 
Askinosie Chocolate) even go so far as to profit-share in a direct trade relationship with farmers. The consumer base for craft chocolate is also generally educated and interested in quality produced with an eye towards ethics. The chocolate, too, when made well, can be of a higher quality and better tasting (Eber and Williams 2012; Presilla 2009).

However, craft chocolate is far from a catch-all solution to problems in the cacao-chocolate supply chain today. For example, the vast quantities of West and Central African cacao being produced are virtually invisible in craft chocolate due to sourcing challenges (Leissle 2013) and, at times, direct prejudice, with derogatory tropes about African cacao quality and labour expressed commonly in the craft chocolate space. In addition, craft chocolate makers buy only small amounts of cacao each year and produce only small amounts of chocolate, just a drop in the bucket of an enormous industry percentage. Cacao farmers selling directly to craft chocolate makers must often rely on relationships characterized by immature or fragile business structures. This overall economic instability and lack of traditional industrial scaling benefit means that many in the craft chocolate space do not make a sustainable income and, due to the deflation overall of chocolate prices as a result of industrial manufacturing, craft chocolate makers find it nearly impossible to set sustainable price points for their bars. Due to the steep learning curve and costly nature of good equipment, many bars produced are also of a lower quality than their relatively high price suggests. This problem is circular and affects overall sustainability of this segment of the industry - the high price of bars and variable quality limits the consumer base, as does the small level of production and distribution. In addition, many of the claims to ethics made by craft chocolate makers are inflated with the same rhetoric employed by fair trade labellers, which is equally problematic.

\section{FutURE DiRECTIONS FOR FINE AND CRAFT CHOCOLATE}

One of the most important critiques of do-gooder consumerism, whether purchasing of fair trade or craft chocolate products, is that of compassionate consumption through double commodity fetishism. The first level of commodity fetishism, in the case of chocolate, relies on the ignorance of consumers as to the social relations of production. Consumers quite regularly purchase and eat chocolate while entirely divorced from any notion of its biography and geography. Moreover, when a second fetish appears in the consumer's world - that of the "touristic quality" of consumption (Lash and Urry 1994:272) or of "compassionate consumption" (Richey and Ponte 2011) - this suggests that food as material culture can be consumed as a way to reflect one's knowledge, worldliness and morality.

It is quite possible that the fine and craft chocolate products described in this essay, linked with sometimes dubious claims of ethics and quality, expand consumption far more than they meet the needs of the people they ostensibly serve throughout the supply chain. Simultaneously, many of these products actively sell a romantic ideal through stereotypical representations of global inequality and injustice - that of the power of the average consumer to figuratively travel through the experience of terroir or to contribute to social justice and alleviate the suffering of developing world farmers by voting with their dollars. This can effectively delink capitalist production and global poverty in consumers' minds, a disconcerting possibility given the clear 
relationship between the two. While there is much to recommend fine and craft chocolate, there is also much left to be done. In other words, the problems of the local-global divide and socially unequal state of cacaochocolate production and consumption described throughout this essay persist in the present day, despite many of our perceived solutions.

In order to address these problems, investment of resources into the following seven areas will be necessary:

- Education - At all points in the cacao-chocolate supply chain, education and training are necessary. We can collectively work to improve our own comprehension of the long socio-historical antecedents of the worst forms of child labour, loss of agrobiodiversity in cacao and cacao producing regions, and challenges in cacao cultivation and chocolate production. This will also aid in putting an end to the exploiter-exploited binary that oversimplifies and stereotypifies notions of cacao farmers worldwide, presently hindering much of the work that needs to be done.

- Research - Further research is necessary in most areas of the cacao-chocolate supply chain, but especially in relation to labour and social inequality. This research should be varied in design and analytical approach and guided by area and subject matter experts. It should be made available to all stakeholders.

- Legislation - Legislation and execution of the law are necessary to improve labour and land rights in primarily cacao producing countries as well as sourcing and consumption practices in primarily chocolate processing and consuming countries.

- Advocacy - Grass roots, rather than top-down, approaches to advocacy are increasingly necessary. These approaches should be rooted in local communities and supported financially and technically by collaborative allies.

- Economics - Buyers must pay more for cacao, uncertified and certified. Both practically and morally, consistent cacao farmer poverty in an industry replete with wealth is unacceptable. Any cacao purchasing scheme should be characterized by standardization, values, transparency, and verification. Certification schemes should be possible to support farmers or cooperatives with limited economic cost. Critiques of certification should be taken seriously and result in innovative change.

- Cooperation - Knowledge and resource sharing among different stakeholders in the cacao-chocolate supply chain should become regular practice. Likewise, industry, governments, certifying bodies, nongovernmental organizations, and consumer groups must work together towards shared goals.

- Prioritization - At present, flavour and high end consumer audiences are the chief priorities of fine cacao and chocolate advocates, as evidenced by the existing industry organizations, marketing schemes, and award competitions. Increased prioritization of accountability for upholding stated values, especially in relation to social and environmental ethics, is urgently needed to avoid the pitfalls of rhetoric obscuring reality. 


\section{SUMMARY}

This essay has demonstrated that many of the existing narratives of chocolate are similar to the point of mythologizing, with little critical analysis of the history and culture of chocolate in Europe and among Europeans, especially as it relates to labour and social inequality. Critical analysis of these social factors, tracing from the ancient history of cacao in Mesoamerica to the present-day state of the chocolate industry and consumption in Europe, demonstrates the complexity of the cacao-chocolate supply chain and its impact on the lived experiences of people throughout the world. It also suggests directions for future education, investment, and action by the growing fine and craft chocolate industry that can promote mutual benefits for producers and consumers. Everyone is implicated in our contemporary food system and everyone, from farmers to consumers, will be involved in creating solutions to its problems. Chocolate's capacity to connect at local and global levels tells us not only about past lives and about how we are right now, but also about how we could be. 


\section{REFERENCES}

Allen, L. L. (2010) Chocolate fortunes: The battle for the hearts, minds, and wallets of China's consumers. New York: American Management Association. http://doi.org/10.1002/tie.20306.

Benzoni, G. (1565) La Historia del Mondo Nvovo di M. Girolamo Benzoni Milanese, \& Mari nuouamente rotrouati, \& delle nuoue cittá da lui proprio vedute, per acqua \& per terra in quattordecci anni. Venetia: F. Rampazetto.

Bergmann, John F. (1969) The Distribution of Cacao Cultivation in Pre-Columbian America. Annals of the Association of American Geographers 59, 85-96. http://doi.org/10.1111/j.1467-8306.1969.tb00659.x.

Berlan, A. (2011) Working Paper. Social Sustainability in Agriculture: An Anthropological Perspective on Child Labour in Cocoa. Manchester Papers in Political Economy. http://doi.org/10.1080/00220388.2013.780041.

Bernardini, G. (2015) Chocolate - The Reference Standard. Bonn: Self-published.

Beliaev, D. - Davletshin, A. - Tokovinine, A. (2010) Sweet Cacao and Sour Atole: Mixed Drinks on Classic Maya Ceramic Vases. In Staller, J. E. - Carrasco, M. D. (eds.) Pre-columbian Foodways: interdiscipilanary Approaches to Food, Culture, and Markets in Ancient Mesoamerica. Springer Science+Business Media, LLC, 257-272. http://doi.org/10.1007/978-1-4419-0471-3_10.

Bonner, D. M. (1999) Beauty, Propriety and Status in a Former British Colony: European Aesthetic Theory and Social Distinctions Based Upon Racial "Appearances" in Dangriga, Belize. Social Analysis: The International Journal of Social and Cultural Practice 43(1), 119-140.

Brelinski, B. (2015) Flavors of Cacao. Retrieved from http://flavorsofcacao.com

Clarence-Smith, W. G. (2000) Cocoa and chocolate, 1765-1914. London; New York: Routledge.

Champlain, S. (1859) A Narrative of a Voyage to the West Indies and Mexico in the Years 1599-1602. Trans. Alice Wilmere, Ed. Norton Shaw. London: Hakluyt Society.

Ciudad Real, A. (1873) Relación breve y verdadera. Madrid: Imprenta d la Viuda de Calero.

Coe, S. D. - Coe, M. (2013) The true history of chocolate. London: Thames \& Hudson.

Daley, S. (2013, March 2) Hungary Experiments With Food Tax to Coax Healthier Habits. The New York Times. Retrieved from http:// www.nytimes.com/2013/03/03/world/europe/hungary-experiments-with-food-tax-to-coax-healthier-habits.html

Davis, D. B. (2007, May 31) He Changed the New World. The New York Review of Books. Retrieved from http://www.nybooks.com/ articles/archives/2007/may/31/he-changed-the-new-world/.

Delamont, S. (1995) Appetites and identities: An introduction to the social anthropology of western Europe. New York: Routledge Press.

Eber, J. - Williams, P. (2012) Raising the Bar: The Future of Fine Chocolate. Vancouver: Wilmor Publishing Corporation.

Echagoyan, P. (1603) Tablas de reduciones de monedas, y el valor de todo genero de plata y oro, y le modo de hazer las cuetas del, y de los derechos. México: Impresas con licencia, Henrico Martinez.

Escalante Arce, P. A. (1992) Códice Sonsonate: Crónicas hispánicas, Vol. I-II. CONCULTURA, Dirección de Publicaciones e Impresos: San Salvador.

Evans, S. T. (1991) Architecture and Authority in an Aztec Village: Form and Function of the Tecpan. In H. R. Harvey (ed.) Land and Politics in the Valley of Mexico: A Two-Thousand-Year Perspective. Albuquerque: University of New Mexico Press, 63-92.

Feldman, L. H. (1985) A Tumpline Economy: Production and Distribution Systems in Sixteenth-Century Eastern Guatemala. Culver City, CA: Labyrinthos.

Fowler, W. R. (1987) Cacao, Indigo, and Coffee: Cash Crops in the History of El Salvador. Research in Economic Anthropology 8 , 139-167.

Fowler, W. R. (1989) The Cultural Evolution of Ancient Nahua Civilizations: The Pipil-Nicarao of Central America. Norman: University of Oklahoma Press.

Fowler, W. R. (2006) Cacao Production, Tribute, and Wealth in Sixteenth-Century Izalcos, El Salvador. In Cameron McNeil (ed.) Chocolate in Mesoamerica: A Cultural History of Cacao, Gainesville: University Press of Florida, 307-321.

García de Palacio, D. (1985) Letter to the King of Spain: being a description of the ancient provinces of Guazacapan, Izalco, Cuscatlan, and Chiquimula, in the Audiencia of Guatemala, with an account of the languages, customs, and religion of their aboriginal inhabitants, and a description of the ruins of Copan. Translated and with notes by Ephraim G. Squier, with additional notes by Alexander von Franzius and Frank E. Comparato, ed. Culver City: Labyrinthos Press.

Gerarde, John (1597) The Herball or Generall Historie of Plantes. London: John Norton. 
Gikandi, S. (2011) Slavery and the culture of taste. Princeton: Princeton University Press.

Gomez, M. A. (2005) Reversing sail : a history of the African diaspora. Cambridge; New York: Cambridge University Press.

Hainmueller, J. - Hiscox, M. - Tampe, M. (2011) Working Paper. Sustainable Development for Cocoa Farmers in Ghana. International Growth Centre.

Henderson, J. S. - Joyce, R. A. - Hall, G. R. - Hurst, W. J. - McGovern, P. E. (2007) Chemical and archaeological evidence for the earliest cacao beverages. Proceedings of the National Academy of Sciences of the United States of America 104(48), 18937-18940. http://doi.org/10.1073/pnas.0708815104.

Houston, S. - Stuart, D. - Taube, K. (1989) Folk Classification of Classic Maya Pottery. American Anthropologist 91, 720-726. http://doi.org/10.1525/aa.1989.91.3.02a00130.

ICCO. (2013) International Cocoa Organization Annual Report 2012/2013. ICCO.

ICCO. (2015) Fine Or Flavour Cacao. ICCO. Retrieved from http://icco.org/about-cocoa/fine-or-flavour-cocoa.html

Kawash, S. (2013) Candy: A century of panic and pleasure. New York: Faber and Faber, Inc.

Landa, D. de - Tozzer, A. M. - Bowditch, C. P.- Herrero y Tordesillas, A. - López Medel, T. - Chi, G.A.-Salazar, F. C. (1941) Landa's Relación de las cosas de Yucatan: a translation. Cambridge: The Museum.

Lash, S. - Urry, J. (1994) Economies of Signs and Space. London; Thousand Oaks: Sage Publications.

Laudan, Rachel (2013) Cuisine and Empire: Cooking in World History (California Studies in Food and Culture). Los Angeles: University of California Press.

Leissle, K. (2012) Cosmopolitan cocoa farmers: refashioning Africa in Divine Chocolate advertisements. Journal of African Cultural Studies, 24(2). http://doi.org/10.1080/13696815.2012.736194.

Leissle, K. (2013) Invisible West Africa: The Politics of Single Origin Chocolate. Gastronomica, 13(3), 22-31. http://doi.org/10.1525/gfc.2013.13.3.22.

León Pinelo, A. (1636) Question moral, si el chocolate quebranta el ayuno eclesiastico. Madrid: la viuda de Juan González.

Lockhart, J. (1992) The Nahuas After the Conquest: A Social and Cultural History of the Indians of Central Mexico, Sixteenth through Eighteenth Centuries. Stanford: Stanford University Press.

López Mendoza, R. (1987) El cacao en Tabasco. México: Universidad Autónoma Chapingo, Dirección de Difusión Cultural, Subdirección de Centros Regionales.

MacLeod, M. (2008) Spanish Central America: A Socioeconomic History, 1520-1720. Austin: University of Texas Press.

Macri, M. J. (2005) Nahua Loan Words From The Early Classic Period: Words for Cacao Preparation on a Río Azul Ceramic Vessel. Ancient Mesoamerica 16, 321-326. http://dx.doi.org/10.1017/S0956536105050200.

Mariscal Haz, B. (ed.) (2000 [1579)] Carta del Padre Pedro de Morales. Mexico City: Colección Biblioteca Novohispana, V. Centro de Estudios Lingüísticos y Literarios, El Colegio de México.

Martyr, P. (1617) De Novo Orbe, or The History of the west Indies. London: Thomas Adams.

McCabe, M. (2015) Fine Chocolate, Resistance, and Political Morality in the Marketplace. Journal of Business Anthropology, 4(1), $54-81$.

McNeil, C. L. (ed.) (2006) Chocolate in Mesoamerica: A Cultural History of Cacao. Gainesville: University Press of Florida.

Merivale, H. (1928) Lectures on colonization and colonies delivered before the University of Oxford in 1839, 1840, \& 1841, and reprinted in 1861. London: Oxford University Press.

Mintz, S. W. (1985) Sweetness and power: The place of sugar in modern history. New York: Penguin Books.

Molina, F. A. (1571) Vocabulario en lengua castellana y mexicana. Mexico: Casa de Antonio de Spinosa.

Nieburg, O. (2014, October 9) The chocolate league tables 2014: Top 20 consuming nations. ConfectioneryNews.com. Retrieved from http://www.confectionerynews.com/Markets/Chocolate-consumption-by-country-2014

Norton, M. (2006) Tasting Empire: Chocolate and the European Internalization of Mesoamerican Aesthetics. The American Historical Review, 111(3), 660-691. http://dx.doi.org/10.1086/ahr.111.3.660.

Powis, T. G. - Valdez Jr., F. - Hester, T. R. - Hurst, W. J. - Tarka Jr., S. M. (2002) Spouted Vessels and Cacao Use among the Preclassic Maya. Latin American Antiquity 13(1), 85-106. http://dx.doi.org/10.2307/971742.

Poynton, S. (2015) Beyond Certification. London: DoSustainability. 
Presilla, M. E. (2009) The new taste of chocolate:A cultural and natural history of cacao with recipes. Berkeley: Ten Speed Press.

Richey, L. A. - Ponte, S. (2011) Brand Aid: Shopping Well to Save the World. Minneapolis: University Of Minnesota Press.

Robertson, E. (2009) Chocolate, women and empire: A social and cultural history. Manchester; New York: Manchester University Press.

Rosenblum, M. (2005) Chocolate: A bittersweet saga of dark and light. New York: North Point Press.

Roys, R. L. (1972) The Indian Background of Colonial Yucatan. Norman: University of Oklahoma Press.

Rózsavölgyi Csokoládé (2015) Rózsavölgyi Csokoládé. Retrieved from http://www.rozsavolgyi.com/en/chocolate/factory-and-shop/45/ workshop.

Ruz Lhullier, A. (1969) La Costa de Campeche en los Tiempos Prehispánicos. México: INAH.

Sahagún, B. (1961 [1575-1577]) Florentine Codex: General History of the Things of New Spain; Book 10 -- The People, No. 14, Part 11, eds. and transl. Arthur J. O. Anderson and Charles E. Dibble, Santa Fe and Salt Lake City: School of American Research and the University of Utah.

Satre, L. J. (2005) Chocolate on trial: Slavery, politics, and the ethics of business. Athens: Ohio University Press.

Smith, M. E. (1973) Picture Writing from Ancient Southern Mexico: Mixtec Place Signs and Maps. Norman: University of Oklahoma Press.

Stuart, D. (1988) The Rio Azul Cacao Pot: Epigraphic Observations on the Function of a Maya Ceramic Vessel. American Antiquity 62 (1), 153-157.

Stuart, D. (2006) The Language of Chocolate: References to Cacao on Classic Maya Drinking Vessels. In MacNeil, C. L. (ed.) Chocolate in Mesoamerica: The Cultural History of Cacao. University Press of Florida: Gainesville, 184-201.

Stubbe, H. (1662) The Indian Nectar, or a discourse concerning CHOCOLATA. London: J.C. for Andrew Crook at the Sign of the Green Dragon in St. Paul's Church-yard.

Sylla, N. S. (2014) The fair trade scandal: Marketing poverty to benefit the rich. Athens: Ohio University Press.

Terrio, S. J. (2000) Crafting the culture and history of French chocolate. Berkeley: University of California Press.

Thompson, J. E. S. (1972) A Commentary on the Dresden Codex. Philadelphia: American Philosophical Society, Memoir 93.

Tulane University. (2015) 2013/14 Survey Research on Child Labor in West African Cocoa Growing Areas. School of Public Health and Tropical Medicine, Tulane University.

Williams, E. (1994) Capitalism and Slavery. Chapel Hill: The University of North Carolina Press.

Winson, A. (1992) The intimate commodity: Food and the development of the agro-industrial complex in Canada. Toronto: Garamond Press.

World Cocoa Foundation. (2014) Cocoa Market Update. World Cocoa Foundation. Retrieved from http://worldcocoafoundation.org/ wp-content/uploads/Cocoa-Market-Update-as-of-4-1-2014.pdf. 